\title{
Suppression of Fireblight in Apple Shoots by Prohexadione-calcium following Experimental and Natural Inoculation
}

\author{
K.S. Yoder ${ }^{1}$ \\ Department of Plant Pathology, Physiology and Weed Science, \\ Virginia Tech Agricultural Research and Extension Center, Winchester, VA 22602 \\ S.S. Miller ${ }^{2}$ \\ U.S. Department of Agriculture, Appalachian Fruit Research Station, Kearneysville, WV 25430 \\ R.E. Byers ${ }^{3}$ \\ Department of Horticulture, Virginia Tech Agricultural Research and Extension Center, Winchester, VA 22602
}

\begin{abstract}
Fireblight, a disease caused by Erwinia amylovora (Burrill) Winslow et al., is an increasingly important disease in apple (Malus $\times$ domestica Borkh.) production throughout the mid-Atlantic region of the United States and elsewhere. Factors related to its increase in prominence include increased planting of highly susceptible scion-rootstock combinations, the use of crabapple pollinizers within high-density orchards, and development of resistance to streptomycin by the fireblight bacterium in some eastern production areas (Jones and Sutton, 1996). Streptomycin resistance has not yet been proven in the mid-Atlantic region, but this concern, together with the increasing planting of highly susceptible scions and rootstocks, heightens the need to avoid cultural practices that increase tree susceptibility. In addition to chemical control, the program for overall management of fireblight includes proper tree nutrition and practices that promote early cessation of growth (Beer, 1990).

In spite of long-term recognition that tree vigor is an important element in fireblight susceptibility (Van der Zwet and Keil, 1979), few reports have addressed the possibility that plant growth inhibitors could reduce susceptibility or suppress infection. Two reports discuss the potential effects of daminozide (Lombard et al., 1982) and other plant growth regulators (Deckers and Daemen, 1993) on shoot growth, secondary bloom and fireblight risk in pear (Pyrus communis L.). We are not aware of published reports with experimental data that confirm a positive or negative effect of plant growth regulators on fireblight development. Prohexadione-Ca is an experimental plant growth regulator currently under study for controlling vegetative shoot growth. The objective of this study was to evaluate the effects of prohexadione$\mathrm{Ca}$ and streptomycin, alone and in combination, on the shoot blight phase of fireblight. An abstract describing a portion of this work has been published (Byers and Yoder, 1997).
\end{abstract}

\section{MATERIALS AND METHODS}

General. Artificially inoculated fireblight research plots involving prohexadione-Ca were established at Virginia Tech AREC, Winchester, Va. in 1994, 1995, and 1997. Field data were also recorded from natural infections in field plots at the U.S. Dept. of AgricultureAppalachian Fruit Research Station (USDA-AFRS), Kearneysville, W.Va., in 1995. Prohexadione-Ca treatments were also applied at Winchester in 1996, but trees were not artificially inoculated and natural infection did not develop.

Received for publication 20 July 1998. Accepted for publication 1 Aug. 1998. Mention of a trade name, proprietary product, or specific equipment does not constitute a guarantee or warranty and does not imply approval to the exclusion of other products that may be suitable. We gratefully acknowledge the technical assistance of Allen Cochran II, William Royston, Jr., and Scott Kilmer. This project was partially supported by BASF Corp., Research Triangle Park, N.C. The cost of publishing this paper was defrayed in part by the payment of page charges. Under postal regulations, this paper therefore must be hereby marked advertisement solely to indicate this fact.

${ }^{1}$ Associate Professor of Plant Pathology.

${ }^{2}$ Research Horticulturist.

${ }^{3}$ Professor of Horticulture.
Trees. Vigorous, well-pruned trees, trained to a central leader, were used in these studies. At Winchester mature 'Rome Beauty'/MM.106 trees were used in 1994 and 'Golden Delicious'/M.7 trees in 1995 and 1997. At Kearneysville in 1995, 16-year-old 'Law Rome'/MM.111 trees were used to study the effects of single and multiple applications of the growth regulator.

Test materials and application. Prohexadione-Ca (3-oxido-4propionyl-5-oxo-3-cyclohexene-carboxylate) was applied as experimental formulations BAS 9054.2 10DF in 1994 and BAS 125 W 10DF in 1995 and 1997. Streptomycin sulfate (Agri-Mycin 17) was included or applied separately as indicated. A spray adjuvant, Regulaid ${ }^{\circledR}$ (polyoxyethylenepolypro-poxypropanol and alkyl 2-ethoxyethanol dihydroxy propane) was included with all prohexadione-Ca treatments at $0.03 \%$ or $0.125 \%(\mathrm{v} / \mathrm{v})$ as indicated. In 1994 treatments were applied dilute with a low pressure hand-wand sprayer. In 1995 and 1997 , treatments were applied dilute to the point of runoff with a single nozzle handgun at $1380 \mathrm{KPa}$. A roller pump operating at $690 \mathrm{KPa}$ was used to apply treatments at Kearneysville.

Inoculation procedures. Inoculum for tests at Winchester was obtained by growing a culture of E. amylovora 1 or $2 \mathrm{~d}$ at $25^{\circ} \mathrm{C}$ on nutrient yeast dextrose agar, and harvesting and suspending the bacteria in a buffer solution containing approximately $1 \times 10^{5}$ cells $/ \mathrm{mL}$ (1994) or $1 \times 10^{8}$ cells/mL (1995 and 1997). Shoot tips were inoculated as indicated in the last leaf node with a No. 25 hypodermic syringe holding one droplet of a bacterial suspension.

1994 Winchester. A small-scale test was conducted with 14 selected, actively growing, shoots per treatment. All test shoots were distributed on four mature 'Rome Beauty' trees, using three or four shoots per treatment per tree. Full bloom occurred on 22 April. Prohexadione-Ca $\left(375 \mathrm{mg} \cdot \mathrm{L}^{-1}\right)+\operatorname{Regulaid}(0.125 \%$, v/v), was applied to individual shoots with a small hand sprayer 2 May 1994. Shoots were measured before shoot tip inoculation 10 May. Fireblight incidence and extent of canker progression on inoculated shoots and length of noninoculated shoots were recorded 30 June. Mean shoot lengths were separated by Waller-Duncan k ratio $t$ test $(P \leq 0.05)$. Frequencies of shoot infection were compared by using a Chi-square test.

1995 Winchester. An experiment was conducted on moderately vigorous 'Golden Delicious' trees using four single-tree replications in a randomized block design. All applications contained Regulaid $0.03 \%$ by volume. One set of trees was treated twice with prohexadione$\mathrm{Ca}\left(250 \mathrm{mg} \cdot \mathrm{L}^{-1}\right)$ at early bloom (20 Apr.) and full bloom (25 Apr.). Other sets were treated once at petal fall on 28 April with prohexadione$\mathrm{Ca}\left(250 \mathrm{mg} \cdot \mathrm{L}^{-1}\right)$, streptomycin $\left(100 \mathrm{mg} \cdot \mathrm{L}^{-1}\right)$, or prohexadione-Ca $(250$ $\left.\mathrm{mg} \cdot \mathrm{L}^{-1}\right)+$ streptomycin $\left(100 \mathrm{mg} \cdot \mathrm{L}^{-1}\right)$. Twenty treated shoots per tree were selected and flagged on 4 May, 10 for inoculation 5 May and 10 for inoculation 12 May ( 1 week and 2 weeks after application to the single-application trees). Fireblight incidence and extent of canker progression in inoculated shoots were assessed on excised shoots 20 June. Growth of shoots on non-inoculated trees was measured on 29 June. Noninoculated strikes were counted and removed 20 June. 
Arcsine transformed means were analyzed with the Waller-Duncan Kratio t test $(P \leq 0.05)$.

1995 Kearneysville. Prohexadione-Ca treatments were applied to 16-year-old 'Law Rome' trees once on 15 May (5-12-cm shoot growth) at 125 or $250 \mathrm{mg} \cdot \mathrm{L}^{-1}$, or twice, once on 15 May and again 16 June, at $125 \mathrm{mg} \cdot \mathrm{L}^{-1}$ in each spray to determine the effects of single or multiple applications on shoot growth. Regulaid was included in all treatments at $0.03 \%$. The experimental design was a randomized complete block with eight single-tree replications. A natural fireblight epidemic developed in the test area in mid-to late June following severe hailstorms on 3 and 11 June 1995. No blossom infection had been observed earlier, but conditions during late May and June 1995 were ideal for shoot blight infection with numerous rain/thunderstorm events and warm temperatures. Terminal shoots were measured 7 Sep. 1995. The number of fireblight strikes per tree was recorded 6 Dec. 1995. Data were analyzed by using analysis of variance and means separated by the Waller-Duncan k ratio $t$ test $(P \leq 0.05)$

1997 Winchester. A study was conducted to test synergistic effects of successive applications of prohexadione-Ca and streptomycin on moderately vigorous, mature 'Golden Delicious' trees using four single-tree replications in a randomized block design. Prohexadione$\mathrm{Ca}$ (125 or $250 \mathrm{mg} \cdot \mathrm{L}^{-1}$ ) was applied 21 May at the $25-\mathrm{cm}$ shoot growth stage. Streptomycin $\left(100 \mathrm{mg} \cdot \mathrm{L}^{-1}\right)$ was applied on 27 May, $1 \mathrm{~d}$ before the first inoculation and $8 \mathrm{~d}$ before the second. Twenty actively growing shoots per tree were selected and flagged on 19 May; 10 were inoculated on 28 May 1 week after the prohexadione-Ca application, and 10 were inoculated on 4 June, 2 weeks after treatment. Fireblight incidence and extent of canker progression were assessed on excised shoots 17 July. Arcsine transformed means were analyzed by WallerDuncan k ratio $t$ test $(P \leq 0.05)$. No noninoculated fireblight strikes were observed in the test trees in 1997.

\section{RESULTS}

1994 Winchester. Prohexadione-Ca treatment significantly $(P \leq$ 0.05 ) suppressed growth of noninoculated shoots measured $60 \mathrm{~d}$ after treatment; treated and nontreated mean shoot lengths were 21.3 and

Table 1. Effects of inoculation with fireblight bacterium and prohexadione-Ca on 'Rome' apple shoot growth and fireblight incidence at Winchester, Va., 1994.

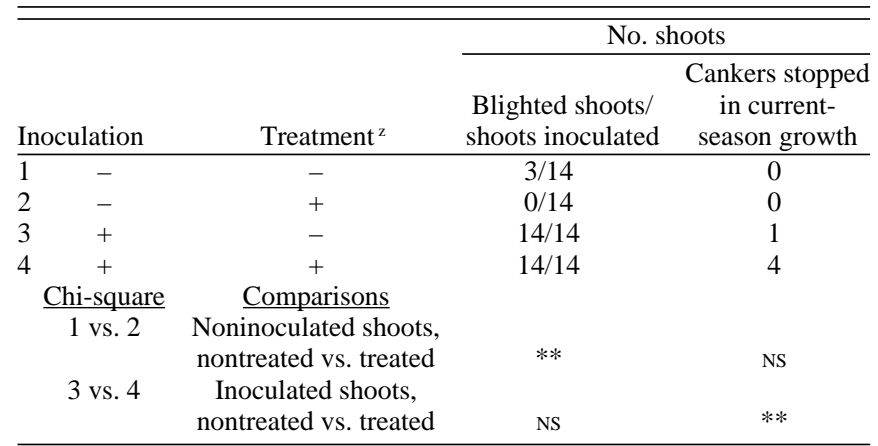

Ns, ** Nonsignificant or significant at $P \leq 0.01$.

$35.6 \mathrm{~cm}$, respectively. All inoculated shoots developed blight whether treated with prohexadione-Ca or not (Table 1), but significantly fewer cankers advanced beyond current season growth on treated shoots. Four natural infection periods with rain and warm weather during bloom had resulted in considerable natural infection in the test block. Three natural infections appeared on nontreated, noninoculated shoots, but none occurred on treated, noninoculated shoots.

1995 Winchester. Prohexadione-Ca treatment reduced shoot growth of non-inoculated shoots by $\approx 50 \%$ and significantly suppressed incidence of infection of shoots inoculated 2 weeks, but not 1 week, after treatment (Table 2). Two applications during bloom (20 and 25 Apr.) significantly reduced the current season growth portion of the canker length when shoots were inoculated $10 \mathrm{~d}$ after the last treatment. When all inoculated shoots were included in the mean, all prohexadione-Ca treatments reduced canker length on current season growth and reduced total canker length of those inoculated 2 weeks, but not 1 week, after treatment. Considering infected shoots only, the current season growth portion of the mean canker length, but not the total canker length, was significantly reduced by prohexadione-Ca treatments 1 or 2 weeks before inoculation. Streptomycin + Regulaid had no effect $(P$ $\leq 0.05$ ) on infection of shoots inoculated 1 or 2 weeks after application. Treatment means for non-inoculated strikes counted 20 June ranged from 1.5 to 11.0 per tree but were highly variable and there was no significant treatment effect $(P \leq 0.05)$.

1995 Kearneysville. A single application of prohexadione-Ca at 125 or $250 \mathrm{mg} \cdot \mathrm{L}^{-1}$, and two applications at $125 \mathrm{mg} \cdot \mathrm{L}^{-1}$, reduced shoot growth (Table 3). Two applications at $125 \mathrm{mg} \cdot \mathrm{L}^{-1}$ or a single application at $250 \mathrm{mg} \cdot \mathrm{L}^{-1}$ were significantly more effective than a single application at $125 \mathrm{mg} \cdot \mathrm{L}^{-1}$. Under natural epidemic conditions all treatments significantly suppressed the number of fireblight shoot strikes per tree by $40 \%$ to $58 \%$.

1997 Winchester. Inoculations on non-treated trees on 4 June resulted in higher incidence of fireblight than those on 28 May. Rains 1-3 June favored continued growth, which may have been slowing due to earlier dry weather, thus increasing shoot susceptibility. Streptomycin alone or in combination with prohexadione-Ca applied the day before inoculation suppressed fireblight incidence on inoculated shoots (Table 4). The prohexadione-Ca effect was greater 2 weeks after application than after 1 week. The most dramatic effect was on the percentage of shoots infected by inoculations 4 June. Two weeks after treatment, growth suppression had begun, and the residual effect of streptomycin applied $8 \mathrm{~d}$ earlier was reduced, although still significant; however, prohexadione-Ca, followed $6 \mathrm{~d}$ later with streptomycin, appeared to give a synergistic effect. This treatment resulted in $97 \%$ control of shoot blight incidence compared with $83 \%$ control by prohexadione-Ca $250 \mathrm{mg} \cdot \mathrm{L}^{-1}$ and $33 \%$ control by streptomycin applied separately at the same time. For inoculations 28 May, when the prohexadione-Ca had not yet really taken effect, streptomycin gave an expected 1-d protective effect against infection. When all shoots inoculated 4 June were included in the mean, all prohexadione-Ca and streptomycin treatments reduced mean total canker length; however, when considering infected shoots only, there was no significant treatment effect $(P \leq 0.05)$ on total canker length of shoots inoculated 1 or 2 weeks after application.

Table 2. Suppression of fireblight incidence and canker length by foliar applications of prohexadione-Ca on 'Golden Delicious' apple trees at Winchester, VA, 1995

\begin{tabular}{|c|c|c|c|c|c|c|c|c|c|c|c|c|}
\hline \multirow{3}{*}{\multicolumn{2}{|c|}{ Treatment ${ }^{2}$}} & \multirow{5}{*}{\multicolumn{2}{|c|}{$\begin{array}{c}\% \\
\text { Shoots } \\
\text { inoculated } \\
12 \text { May } \\
\text { infected } \\
\text { 20 June }\end{array}$}} & \multicolumn{8}{|c|}{$\begin{array}{l}\text { Mean canker length }(\mathrm{cm}) 20 \text { June composed by current-season } \\
\text { growth and total canker length as affected by inoculation date }\end{array}$} & \multirow{5}{*}{$\begin{array}{l}\text { Mean shoot } \\
\text { growth }(\mathrm{cm}), \\
\text { noninoculated } \\
\text { trees, } 29 \text { June }\end{array}$} \\
\hline & & & & \multicolumn{4}{|c|}{ All inoculated shoots } & \multicolumn{4}{|c|}{ Infected shoots only } & \\
\hline & & & & \multirow{2}{*}{\multicolumn{2}{|c|}{$\begin{array}{c}\text { In current- } \\
\text { season growth }\end{array}$}} & \multirow{2}{*}{\multicolumn{2}{|c|}{ Total length }} & \multirow{2}{*}{\multicolumn{2}{|c|}{$\begin{array}{c}\text { In current- } \\
\text { season growth }\end{array}$}} & \multirow{2}{*}{\multicolumn{2}{|c|}{ Total length }} & \\
\hline Prohexadione-Ca & Streptomycin & & & & & & & & & & & \\
\hline$\left(250 \mathrm{mg} \cdot \mathrm{L}^{-1}\right)$ & $\left(100 \mathrm{mg} \cdot \mathrm{L}^{-1}\right)$ & & & 5 May $^{y}$ & 12 May & 5 May & 12 May & 5 May & 12 May & 5 May & 12 May & \\
\hline- & - & $\begin{array}{ll}-- \\
-\end{array}$ & $100 \mathrm{~b}^{\mathrm{x}}$ & $8.5 \mathrm{~b}$ & $13.9 \mathrm{~b}$ & $19.2 \mathrm{a}$ & $32.8 \mathrm{~b}$ & $9.2 \mathrm{c}$ & $13.9 \mathrm{~b}$ & $20.8 \mathrm{a}$ & $32.8 \mathrm{a}$ & $27.4 \mathrm{~b}$ \\
\hline+ & - & 28 Apr. & $65 \mathrm{a}$ & $6.9 \mathrm{ab}$ & $7.5 \mathrm{a}$ & $15.3 \mathrm{a}$ & $18.7 \mathrm{a}$ & $7.6 \mathrm{ab}$ & $11.4 \mathrm{a}$ & $17.0 \mathrm{a}$ & $27.9 \mathrm{a}$ & $14.4 \mathrm{a}$ \\
\hline+ & - & 20, $25 \mathrm{Apr}$. & $56 \mathrm{a}$ & $5.9 \mathrm{a}$ & $5.3 \mathrm{a}$ & $11.9 \mathrm{a}$ & $16.3 \mathrm{a}$ & $6.9 \mathrm{a}$ & $9.1 \mathrm{a}$ & $14.0 \mathrm{a}$ & $26.0 \mathrm{a}$ & $13.5 \mathrm{a}$ \\
\hline- & + & 28 Apr. & $93 \mathrm{~b}$ & $8.0 \mathrm{ab}$ & $13.2 \mathrm{~b}$ & $19.0 \mathrm{a}$ & $31.1 \mathrm{~b}$ & $8.6 \mathrm{bc}$ & $14.2 \mathrm{~b}$ & $21.3 \mathrm{a}$ & $33.7 \mathrm{a}$ & --- \\
\hline+ & + & $28 \mathrm{Apr}$. & $46 \mathrm{a}$ & $7.0 \mathrm{ab}$ & $4.9 \mathrm{a}$ & $16.2 \mathrm{a}$ & $10.4 \mathrm{a}$ & $8.4 \mathrm{bc}$ & $11.1 \mathrm{a}$ & $19.4 \mathrm{a}$ & $28.4 \mathrm{a}$ & $14.1 \mathrm{a}$ \\
\hline
\end{tabular}

${ }^{2}$ All sprays contained Regulaid $(0.03 \%$ by volume $)$

yate of inoculation in May.

${ }^{\mathrm{x}}$ Mean separation within columns by Waller-Duncan $\mathrm{k}$ ratio $t$ test $(P \leq 0.05)$. 
Table 3. Effects of concentration and timing of prohexadione-Ca sprays on 'Law Rome' apple shoot growth and fireblight incidence at Kearneysville, W.Va., 1995.

\begin{tabular}{lccc}
\hline \hline $\begin{array}{l}\text { Prohexadione-Ca } \\
\left(\mathrm{mg} \cdot \mathrm{L}^{-1}\right)^{\mathrm{z}}\end{array}$ & Timing & $\begin{array}{c}\text { Fireblight } \\
\text { strikes } \\
\text { per tree }\end{array}$ & $\begin{array}{c}\text { Mean } \\
\text { terminal }\end{array}$ \\
\hline 0 & --- & $94 \mathrm{a}^{\mathrm{w}}$ & $54.7 \mathrm{a}$ \\
125 & $5-12 \mathrm{~cm}$ shoot growth & $56 \mathrm{~b}$ & $48.1 \mathrm{~b}$ \\
250 & $5-12 \mathrm{~cm}$ shoot growth & $54 \mathrm{~b}$ & $41.4 \mathrm{c}$ \\
125 & $5-12 \mathrm{~cm}+4-5$ wk later & $39 \mathrm{~b}$ & $40.0 \mathrm{c}$ \\
\hline
\end{tabular}

${ }^{2}$ All sprays contained Regulaid ( $0.03 \%$ by volume).

${ }^{y}$ Fireblight strikes recorded 6 Dec. 1995.

${ }^{x}$ Terminal shoot growth measured 7 Sept. 1995.

${ }^{\text {w} M e a n ~ s e p a r a t i o n ~ w i t h i n ~ c o l u m n s ~ b y ~ W a l l e r-D u n c a n ~} \mathrm{k}$ ratio $t$ test $(P \leq 0.05)$.

\section{DISCUSSION}

Use of the beneficial growth suppressant effect of prohexadione$\mathrm{Ca}$ to reduce tree susceptibility would represent a logical but novel addition to the limited arsenal of fireblight management practices. Growth suppression in the post-bloom period could provide welcome relief for shoot blight control in some high-risk situations where the use of streptomycin after petal fall is discouraged to limit development of resistance to this chemical. Potential synergistic effects of combinations of prohexadione-Ca with streptomycin or of prohexadione-Ca followed by streptomycin at late bloom hold particular interest for reducing disease pressure, thereby prolonging the effectiveness of streptomycin in areas where resistance of E. amylovora to streptomycin has not yet been identified.

Consistent suppression of incidence of infection of inoculated shoot tips, and less consistent but occasional reduction in the length of the canker occurring in current season growth of infected shoots (1995), suggest that the effect of prohexadione-Ca treatment on fireblight control is more likely to be its reduction of shoot tip susceptibility than its reduction of the susceptibility of more proximal portions of the shoot or of previous years' growth. Reduction in canker length of current season growth, when it occurred, probably was due to inhibition of growth near the shoot tip during the incubation period before the onset of symptoms and canker extension.

Optimum rates and timing(s) for prohexadione-Ca application for continued post-bloom fireblight suppression need to be determined. The late-bloom to petal-fall timing should allow opportunity for growth suppression to be initiated while some residual activity remains from late-bloom applications of streptomycin or other bactericides. Note that the tests at Winchester were conducted on vigorously growing shoots selected before treatment to assure a strong challenge,
Table 4. Suppression of fireblight incidence and canker length by applications of prohexadione-Ca and streptomycin to 'Golden Delicious' apple trees, Winchester, Va., 1997.

\begin{tabular}{|c|c|c|c|c|}
\hline \multicolumn{2}{|c|}{ Rate $\left(\mathrm{mg} \cdot \mathrm{L}^{-1}\right)$, and timing ${ }^{2}$} & \multirow{2}{*}{\multicolumn{2}{|c|}{$\begin{array}{l}\text { \% Inoculated shoots } \\
\text { infected } 17 \text { July; } \\
\text { inoculated on: }\end{array}$}} & \multirow{3}{*}{$\begin{array}{c}\text { Mean canker } \\
\text { length }(\mathrm{cm}) \\
17 \text { July of shoots } \\
\text { inoculated } 4 \text { June }\end{array}$} \\
\hline \multirow{2}{*}{$\begin{array}{l}\text { Prohexadione-Ca } \\
21 \text { May }\end{array}$} & \multirow{2}{*}{$\begin{array}{l}\text { Streptomycin } \\
27 \text { May }\end{array}$} & & & \\
\hline & & 28 May & 4 June & \\
\hline$\overline{0}$ & 0 & $48 \mathrm{~b}^{\mathrm{y}}$ & $75 \mathrm{~d}$ & $12.1 \mathrm{~b}$ \\
\hline 125 & 0 & $32 \mathrm{ab}$ & $20 \mathrm{~b}$ & $2.2 \mathrm{a}$ \\
\hline 250 & 0 & $25 \mathrm{ab}$ & $13 \mathrm{~b}$ & $0.4 \mathrm{a}$ \\
\hline 0 & 100 & $18 \mathrm{a}$ & $50 \mathrm{c}$ & $4.8 \mathrm{a}$ \\
\hline 250 & 100 & $16 \mathrm{a}$ & $2 \mathrm{a}$ & $0.7 \mathrm{a}$ \\
\hline
\end{tabular}

${ }^{\mathrm{z}}$ All prohexadione-Ca sprays contained Regulaid ( $0.03 \%$ by volume).

${ }^{\mathrm{y}}$ Mean separation within columns by Waller-Duncan k ratio $t$ test, $P \leq 0.05$.

then treated and inoculated. In practice, season-long effectiveness of prohexadione-Ca for shoot blight suppression would probably be proportional to the early setting and sustained suppression of terminal buds. Under natural inoculum conditions at Kearneysville, a single application of prohexadione-Ca at $125 \mathrm{mg} \cdot \mathrm{L}^{-1}$ at the $5-12-\mathrm{cm}$ shoot growth stage gave $40 \%$ control of shoot blight infection. A second application 4-5 weeks later increased this to $62 \%$ control.

Choice of number, rate, and timing of applications may be determined as much by pomological and label considerations as by the ideal choice for effect on fireblight management, but considerations for several uses may be quite compatible. Deckers and Daemen (1993) expressed concern that some plant growth regulators could increase fireblight risk on pear by stimulating secondary bloom production. However prohexadione-Ca's effect on secondary bloom of apples appears to be minimal (Byers and Miller, unpublished data).

\section{Literature Cited}

Beer, S.V. 1990. Fire blight, p. 61-63. In: A.L. Jones and H.S Aldwinckle (eds.). Compendium of apple and pear diseases. Amer. Phytopathol. Soc., St. Paul, Minn.

Byers, R.E. and K.S. Yoder. 1997 The effect of BAS-125W on apple tree growth, fruit quality, and fireblight suppression. HortScience 32:557. (Abstr.)

Deckers, T. and E. Daemen. 1993. Influence of chemical growth regulation on the host susceptibility of pear trees for fire blight. Acta Hort. 338:205-215.

Jones, A.L. and T.B. Sutton. 1996. Fire blight, p. 5-7. In: Diseases of tree fruits in the east. Ext. Bul. NCR 45. Michigan State Univ. E. Lansing.

Lombard, P.B., P.H. Westigard, J.G. Strang, R.B. Allen, and D.N. Joy. 1982. Effect of nitrogen and daminozide on shoot growth for pear psylla suppression and on 'Bartlett' pear performance. HortScience 17:668-669.

Van der Zwet, T. and H.L. Keil. 1979. Fire blight-A bacterial disease of rosaceous plants. U.S. Dept. Agr., Agr. Hdbk. 510. 